\title{
Sokrates: Düşünce ile Eylemlerinin Tutarsızlığı
}

DOI: 10.26466/opus.672459

Ferhat Kutluay *

* Dr. Öğr. Üyesi, Siirt Üniversitesi, Fen-Edebiyat Fakültesi, Siirt/Türkiye E-Posta: kutluayfirat@gmail.com

ORCID: 0000-0001-7403-8675

\section{Öz}

Düşünce tarihinde, adından sıkça söz ettiren birçok önemli isim yer almaktadır. Bu isimlerin başında gerek ortaya koyduğu düşünceleri ve gerek sergilediği eylemleriyle kuşkusuz çok uzak bir geçmişte yaşamış olan Yunanlı filozof Sokrates'in olduğu hemen göze çarpmaktadır. Bunun belki de en önemli nedeni, Sokrates'in düşünceleri ve eylemleri neticesinde önce hapse atılması ve akabinde dramatik bir şekilde idam edilmiş olmasıdır. Sokrates'in kendi yaşamındaki kararlılığı ve en önemlisi düşünceleri ile eylemleri arasındaki ilişkinin tutarlı̆̆ herkesin malumudur. Ama Sokrates'in düşünceleri ile eylemleri arasındaki ilişkiye biraz daha yakından bakıldığııda, zaman ile mekânın gerek dini ve gerek siyasi koşulları da dikkate alındı̆̆ında onun pek de tutarlılık içerisinde olmadı̆̆ anlaşılmaktadır. Dolayısıyla bu çalışma öncelikle Sokrates'in düşünceleri ile eylemleri arasındaki ilişkiden yola çıkarak, Sokrates'in düşünce ile eylemleri arasındaki tutarsızlı̆̆ı nedenleri ile birlikte ortaya koymuştur. Bu çalışma Daha sonra Sokrates'in tutarsızlı̆̆ın göz önüne alarak onun, sadece mahkûm edilmesi noktasında, bilindiğinin aksine herhangi bir haksızlık durumunun söz konusu olmadığını da ortaya çıkarmıştır.

Anahtar Kelimeler: Sokrates, demokrasi, yasa, düşünce, ifade özgürlüğ̈̈, 


\title{
Socrates: Inconsistency of His Thought and Actions
}

\begin{abstract}
Throughout the history of thought there have been many significant names which have been frequently mentioned. A Greek philosopher, Socrates, stands out as he is one of the leading person with his presented thoughts and his exhibited deeds. One of main reasons of this might be Socrates' thoughts and his deeds which led him into prison and then his dramatically execution. The determination in his own life and the coherence of the relationship between his thoughts and his deeds is clearly well-known by everybody. But when more closely looking at this relationship between his thoughts and his deeds, it can be understood that no coherence can be relatively mentioned while paying attention to religion and political condition of the time and place in which he lived. So, this study mainly unveiled the incoherence between Socrates' thoughts and his deeds with their reasons by setting out his thoughts and his deeds. This study also tried to reveal that there has been no unrighteousness contrary to widely conceived, taking into account this incoherence.
\end{abstract}

Keywords: Socrates, democracy, law, Thought, freedom of expression 


\section{Giriş}

Felsefe tarihinde gerek düşünceleri ve gerek eylemleri itibarı ile ilk akla gelen isimlerin başında, şüphesiz M.Ö. 470-399 yılları arasında Atina'da yaşamış olan Yunanlı düşünür Sokrates'in olduğu hepimizin malumudur. Hatta İngiliz düşünür Whitehead'ın, bütün bir Batı felsefesi Platon'un eserine düşürülen dipnotlardan ibarettir (Whitehead 1979, s.39) diyerek aslında bir nevi onun hocası olan Sokrates'e atıfta bulunarak isminin akla gelmesi bağlamında ona işaret ettiğini söylersek hiç yanılmış olmayız. Çünkü düşünce tarihinde Platon gibi büyük bir düşünürü Platon yapan, hocası olan Sokrates'in kendisi olduğu kimse tarafından yadsınamaz. Diğer bir ifadeyle felsefi anlamda Platon gibi bir düşünürün entelektüel kariyeri, Sokrates'e atıf yapılarak açıklanmak durumundadır ya da en azından öyle açıklanabilir (Magee 2001, s.7). Ama böylesine büyük bir popülariteye sahip olan birinin yani Sokrates' in ileri yaşına rağmen (70 yaş) Atina sokaklarında sergilediği bazı eylem ve söylemlerinden dolayı kendisine birtakım suçlamalarda bulunulmuş ve bu nedenle hapse atılarak, daha sonra idam edilmiştir.

Sokrates hapishanede olduğu sıralarda yakın arkadaşı olan Kriton ve diğer arkadaşları tarafından kendisine firar etmesi teklif edildiğinde, Sokrates bu teklifi gerekçe olarak yaşadığı kent ya da devlet olan Atina'nın yasalarını öne sürerek kabul etmemiştir. Daha net bir ifadeyle Sokrates, yaşadığ 1 kentin yasalarına bir nevi ne kadar saygılı olduğunu ve aynı şekilde herkesin de yasalara karşı saygı göstermesi gerektiği bağlamında kaçma fikrini kesin bir dille ret etmiştir. Bu bağlamda sorulması gereken iki temel soru olduğu kanaatindeyiz. Sorulması gereken ilk soru; Sokrates eğer yasalara karşı saygılı olunmasına işaretle hapishaneden kaçmayarak kendisi hakkında verilen cezaya razı oluyorsa, Sokrates' in daha başta yaptığı eylemlerin suç teşkil ettiğini veya en azından suç teşkil edeceğinin farkında olduğunu göstermez mi? Diğer bir ifadeyle Sokrates'in gerçekten sokaklardan hapishaneye giden yolda, sokaklarda sergilediği eylemleri ile hapishanede imkânı olmasına rağmen yaşadığı kentin yasalarını öne sürerek firar etmemesi, onun sergilediğ $i$ eylemleri ile yasalara bakış açısında bir tezatlığın söz konusu olduğu söylenemez mi? Nihayetinde yasalara karşı saygılı olunması isteniliyorsa, bu tür eylemler sergilemekten mümkün mertebe kaçınılması gerekmektedir. Yok, eğer bu tür eylemler sergilenmeye devam ediliyorsa, yasalara karşı saygılı 
olunmasını ve başkalarından saygılı olunmasını istemek bir tür paradoks yaratmaktadır. İkinci soru; herkesin yasalara karşı saygılı olmasını istemek ve kendisinin de yasalara karşı saygılı olduğunu söyleyen ama bu yasalar gereği suçlu bulunan Sokrates'in gerek kendisinin, eşinin, arkadaşlarının ve gerek biz insanlar tarafindan bu durumun bir haksızlık olarak nitelendirilmesi ne kadar doğru olur?

Yukarıda yer alan sorular Sokrates'in sokaklarda sergilediği eylemlerdeki hedeflerini sorgulamaktadır. Bu soruların yanıtını bulmaya çalışmak, Sokrates gibi büyük bir düşünürü küçümsemek ya da aşağılamak bağlamında ona bir saldırı olarak yorumlanmamalıdır. Amacımız, özellikle altını çizmek gerekirse Platon'un ve diğer bazı düşünürlerin bize aktardığı Sokrates' in kendi yaşamı, düşünceleri ve eylemleri arasında tutarlılık söz konusu olup olmadığının analizini yapmaktır. Buna mukabil Sokrates'in idam edilme hadisesi konusunda ise kendisine tamamen haksızlık yapıldığı kanaatinde olup, bunun üzerinde durma gereği bile duymamaktayız. Dolayısıyla bu çalışmanın temel amacı Sokrates' in hangi inanç ya da ideolojiye sahip olduğunu bulmak veyahut onun sahip olduğu inanç ve ideolojinin yaşadığı kente uyup uymadığ 1 değil, tersine Atina kent devletinin bir yurttaşı olarak bilinen Sokrates' in Atina kent devletinin sokaklarında, pazarlarında ve çarşılarında gezerek insanlara soru sorması, - özellikle gerek toplum ve gerek yönetim için her zaman hassas olan siyasi ve dini konularda - iddia edildiği üzere kafaları karıştırıp karıştırmadığı ve eğer kafaların karışmasına sebep olduysa bu doğrultuda yasalara karşı gelip gelmediğini ortaya çıkarmaktır. Yasalara karşı saygılı olunması gerektiğine dikkati çeken ve bu doğrultuda hareket ettiğini göstermeye çalışan Sokrates' in, eğer yasalara karşı geldiği ortaya çıkarsa, bu durumda onun suçlu bulunarak mahkûm edilmesi yerinde bir karar olacağı gibi, onun kendi eylemleri ve düşünceleri arasında da bir tezatlık olduğu ortaya çıkmış olacaktır.

\section{Sokrates'in Eylemleri ve Yasalar}

Düşünce tarihinde Sokrates isminin neredeyse ilk akla gelen isimlerin başında zikrediliyor olması veyahut bizler tarafından günümüze kadar isminin unutulmamasınn sebebinin elbette onun sadece Platon gibi büyük bir düşünürün hocası olmasından ibaret olduğu söylenemez. Sokrates, her ne kadar 
ortaya attığ felsefi fikirleri kendisinden sonra gelen birçok düşünürü etkilemesi bağlamında büyük bir popülariteye sahip olduğu söylenilse de, aslına bakıldığında daha çok onun bu popülaritesinin, geçmişten günümüze çoğu insan tarafından haksızlık olarak nitelendirilecek bir şekilde Atina sokaklarından hapishaneye giden ve ardından idam edilmesiyle sonuçlanan dramatik bir hikâye ile sona ermesinden kaynaklandığı söylenebilir. Bu hikâye onun düşünce tarihinde hiç unutulmamasına ve ayn zamanda düşünce tarihinin ilk şehidi olarak anılmasına yol açacak kadar büyük bir öneme sahip olmasına yol açmıştır. Bu nedenle öncelikle Sokrates'i Atina sokaklarından hapishaneye ve ardından idama kadar götüren sürece kısaca değinmekte fayda vardır.

Sokrates'in öğrencisi olan Platon ile felsefe tarihçisi ve aynı zamanda biyografi yazarı Diogenes Laertios'un bize aktardığı kadarıyla Sokrates'in; Atina sokaklarında, çarşılarında ve pazarlarında yalınayak gezerek önüne gelen insanların ama daha çok gençlerin kafalarını karıştırmak suretiyle yoldan çıkarmak, yaşadığı Atina kentinin Tanrılarına inanmamak ve hatta bu Tanrıların yerine başka Tanrılar icat ederek (Laertios 2019, s. 74) Atina kent devletinin yasalarına karşı geldiği iddia edilmiştir. Bu nedenle Atina kent devletinin yönetiminde bulunan demokrasi taraftarlarınca mahkûm edilmiş ve sonuç itibarıyla M.Ö. 399 yılında Atina kent mahkemesinin beş yüz kişiden oluşan jürisinden iki yüz yirmiye karşı iki yüz seksenin (Cevizci 2010, s. 72) oyuyla suçlu olduğuna kanaat getirilerek daha sonra kendisine baldıran zehri içirtilerek idam edilmiştir. Böylelikle Sokrates düşünce tarihinde filozoflar içinde ölüme mahkûm edilerek ölen/öldürülen ilk filozof olarak düşünce tarihinin kayıtlarına geçmiştir (Laertios 2019, s. 74). Sokrates' in kendisine yöneltilen bu suçlamalardan dolayı mahkûm edilerek daha sonra idam edilmiş olması, günümüze kadar taraflı tarafsız neredeyse herkes tarafından dramatik ve aynı zamanda haksız bir şekilde öldüğü veya daha doğru bir ifadeyle öldürüldügü kanaatini oluşturmuştur.

Sokrates'in mahkûm edilme ve akabinde idam edilme hadisesi, iki önemli hususa yol açmıştır. Birinci husus; Sokrates' in tutuklu olduğu sıralarda Atina kent devleti, yönetimde bulunan Oligarşi yanlıların uzaklaştırılmasıyla Demokrasi taraftarlarınca yönetilmeye başlanılmıştı. Oysa düşünce tarihinin iki önemli düşünürü olan Platon ve Aristoteles'e göre Yunan kent devletlerinde demos (halk) vardı ama demokrasi yoktu çünkü yoksullardan, köle-esirlerden, kadın ve çocuklardan oluşan laikos'un (kalabalık) yönetime katılma 
hakkı kesinlikle söz konusu değildi. Laikos'u dışarıda tutan bu Cumhuriyet ve demokrasiye, Aristokrasi demek belki de daha uygun olabilir. Bu bakımdan İdealist Platon ile realist Aristoteles, demokrasiye ve onun yarattığı kargaşaya karşı bir cephe içerisinde olmuşlardır (Güvenç 1995, s. 22-23). Ama Sokrates'in Atina kentinin yönetiminde bulunan demokrasi taraftarlarınca idam edilme hadisesi, onların demokrasiye daha fazla cephe almasına yol açmıştır. İkinci husus ise; yüzyılları aşarak günümüze kadar bu hadiseye ilgi duyan neredeyse herkes tarafından Sokrates'e büyük bir haksızlık yapıldığı ve aynı zamanda onun kendi yaşamındaki düşüncelerinde ve eylemlerinde tutarlı olduğu ve canı pahasına da olsa onlardan vazgeçmeyerek ne kadar kararlı olduğu zihinlere kazınmasına sebep olmasıdır.

Sokrates'in suçlandığı bu dönemde Peloponnes Savaşının ${ }^{1}$ son demlerinin yaşandığı ve bu savaş genel itibariyle değerlendirildiğinde Atina'nın mağlubiyeti ile sonuçlanması üzerine M.Ö. 404'de Sparta yanlısı oligarşi (zenginlerden oluşan azınlık yönetimi) taraftarlarının yönetime geçerek, aralarında Sokrates'in öğrencisi olan Kritias'ın da yer aldığı otuz kişiden meydana gelen ve demokrasiyi desteklediği bilinen 1500 civarında yurttaşını ölüme göndermesi üzerine ayaklanan Atina halkının demokrasi taraftarlarını yeniden başa geçirmesinin olduğu bir dönemdir (Arslan 2010b, s. 141-142). En önemli yönetim biçimlerinden olan ve ilk olarak Atina'da ortaya çıtığ için literatüre "Atina Demokrasisi" olarak da geçen bu yönetim biçiminin en temel konularından bir tanesi de yurttaşlık meselesidir. Çünkü demokraside yurttaş olma hakkına sahip olanlar, yönetimin her aşamasında pay sahibi olduğu anlamına geldiği için, bu mesele büyük bir hassasiyet içermektedir.

Yunan dünyasının, aralarında kimi zaman farklar olmakla beraber, diğer kent devletlerinde olduğu gibi Atina kent devletinde de o dönem içerisinde

\footnotetext{
${ }^{1}$ Peloponnes Savaşı; Atina ile Sparta arasında i.ö. 431-404 yıllan arasında, yirmi yedi yıl süren savaş, 'Peloponnesos Savaşı' olarak bilinir. Aslında Atina-Sparta çatışması bu savaşın çok öncesinde başlamıştı. Atina'nın Delos Birliği'nin en güçlü üyesi olarak tüm avantajları kendi lehine kullanması, Aigina, Korinthas ve Megara gibi önemli ticaret kentlerinin çıkarına dokunuyordu. Sparta da Yunan dünyasının önderliğinin Atina'nın elinde bulunmasından rahatsızık duymaktaydı. Gerçekte Atina'nın güçlenip bir imparatorluk haline gelmesi, Delos Birliği'nin bir sonucu idi. Atina'nın diğer Yunan kentleri aleyhine güçlenmesi, bu kentlerin bağımsızlığı açısından ciddi bir tehlike oluşturuyordu. Atina, çıkarları doğrultusunda bir arada hareket eden Aigina ve Korinthos'u yenilgiye uğratmıs (i.ö.456), Sparta ile de önce 5 yıllık (i.Ö. 451), sonra da otuz yıllık bir antlaşma (i.ö. 445) imzalamıştı. Böylece Sparta, Atina imparatorluğu'nu (Delos Birliği) kabullenmiş oluyordu. Fakat bu kabulleniş pek fazla sürmedi ve sonunda beklenen savaş patlak verdi (Tekin 1998, s.82-83).
} 
yurttaş olmak, bazı koşulları yerine getirmekle mümkün olmaktaydı. Bu koşullardan bazıları, öncelikle bir insanın yargılamaya ya da yasamaya katılma hakkı olması gerekmekteydi. Böyle bir hak söz konusu olduğunda ise o kişiye yurttaş denilmekteydi. Buna sahip olabilmek için de çocuk, kadın ve köle-esir olmamak ve bununla birlikte belirli bir miktarda (bu miktar Yunanistan'ın kent devletlerinde, zaman ve koşullara göre değişebilmektedir) özel mülkiyete sahip olmak gerekmektedir. Bu koşulların yanında Yunanistan'ın bazı kent devletlerinde yurttaş olmak için, kimi zaman ve durumlarda yürürlükte olmak üzere, iş̧̧i olmamak da gerekmektedir (Aristoteles 2018, s.91). Bununla birlikte Sokrates'in yaşadığı dönem (470-390) Atina'sında yönetim biçimi; kimi zaman tiranlık (tek kişinin olduğu zorba yönetimi), kimi zaman aristokrasi (soylulardan oluşan azınlık yönetimi) olmuşsa da ama yönetim biçimi çoğunlukla demokrasi (fakirlerden oluşan çoğunluk yönetimi) olmuştur (Aristoteles 2017, s.1-45). Ama bir bütün olarak bakıldığında Sokrates, daha çok demokrasi ile yönetilen bir zaman diliminde ve mekânda hayatını idame etmiştir.

Yukarıda adı geçen dönemin Yunan dünyasında Aristoteles'e göre demokrasi, hem özgür yurttaş olup hem de zengin olmayanlar çoğunluk olup yönetimin başına geçtikleri zaman buradaki rejimin ismi demokrasi olur (2018, s. 130). Diğer bir ifadeyle demokrasi, sahip olduğu oyu sayesinde yönetme yetkisinin bütün yurttaşların elinde olmasıdır (Montesquieu 2016, s. 52). O dönem içerisinde Yunan dünyasında devletlerin küçük kent devletleri şeklinde olmasından kaynaklı nüfusun az olması, tüm yurttaşların herhangi bir karar alınırken sürece doğrudan katılması şeklinde gerçekleşmekteydi. Bu şu anlama gelmektedir; Atina'da tüm yurttaşların herhangi bir karar alma sürecine doğrudan katılması, orada "doğrudan demokrasi"² denilen demokrasinin en önemli ya da en eski türünün olduğunu göstermektedir.

Sokrates'in köle olmaması ve belirli bir miktardaki özel mülkiyete sahip olması, onun Atina kent devletinin bir yurttaşı olmasıyla birlikte siyasal açı-

\footnotetext{
2 Doğrudan demokrasi: "Demokrasinin tarihte görülen ilk ve en eski şeklidir. Siyasal karar alma hakkının bütün yurttaşlara ait olduğu ve parti benzeri politik organizasyonların dolayımındın geçmediği yönetim. Doğrudan demokrasinin ilk örneğine milattan önce beşinci yüzyılda Yunan kent devletinde, söz gelimi Atina'da rastlanır. Toplam nüfusu kırk bini aşmayan, bu nüfusun üçte ikisini meydana getiren kadınlarla kölelerin katılamadığı bu demokrasi, Yunanlı özgür ve erkek yurttaşların katılabildikleri bir demokrasiydi." (Cevizci 2013, s. 493).
} 
dan herhangi bir karar alınırken kendisin de kararların alınma sürecinde doğrudan bir pay sahibi olduğunu bize göstermektedir. Dolayısıyla Sokrates Atina kent devletinin bir yurttaşı olması ve onun Atina kent devletinin bir yurttaşı olarak da, Atina kent devletinin yasalarını kabul ettiği ya da yasalara karşı sorumlu olduğu anlaşılmaktadır. Aksi durum onun Atina kent devletinin bir yurttaşı olamayacağının ya da Atina kent devletinde yaşamayacağının bir kanıtı olur. Böylelikle Sokrates yurttaşı olduğu Atina kent devletinin yasalarının dışına çıkmayacağını, çıktığı zamanda suç işlemiş olacağını önceden kabul etmiş olduğu anlaşılabilir ya da böyle bir anlama geldiği söylenebilir.

Yukarıdaki anlatılardan yola çıkıldığında Atina kent devletinin bir yurttaşı olarak Sokrates, mahkeme başkanı ve jüri üyeleri önünde kendisine gençleri yoldan çıkarmak, kentin Tanrılarına inanmadığı ve onun yerine başka tanrılar icat ettiği yönündeki suçlamalarına karşılık, kendisinin aksine Tanrılara inandığı yönünde beyanda bulunarak bu suçlamaları ret etmiştir (Platon 2019a, s.43-45). Sokrates, bu yönde savunmasını yaparken çoğu yerde Tanrı'nın ismini ağzına alarak ya da Tanrılar üzerine yemin ederek, Tanrılara inandığını zaten bir şekilde ima etmektedir. Hatta Sokrates kendisini Tanrı tarafından görevlendirilmiş olarak idrak ettiği için Apollon gibi bir Tanrı'ya iman etmiştir (Direk 2014, s.54). Aynı şekilde Sokrates, gençleri yoldan çıkarmak suretiyle kendisine isnat edilen suçlamaları da kesin bir dille kabul etmemiştir. Bununla birlikte Sokrates' in mahkûmiyeti esnasında ve idam edilmeden önce, yaşadığı Atina kentinin mevcut yönetim biçimi olan demokrasiyi de kabul ettiğini ya da en azından kabul etmek zorunda olduğunu varsayabiliriz. Yönetim biçimi olan demokrasiyi kabul etmemiş olsaydı, gerek bir yurttaş olarak sayılması ve gerek orada yaşaması zaten mümkün olamayacağı pekâlâ söylenebilir.

Savunmasında kendisine yöneltilen gerek kentin tanrılarına inanmadığı ve gerek gençleri yoldan çıkardığı yönündeki suçlamaları kesin bir dille ret eden Atina yurttaşı olan Sokrates sokaklarda, pazarlarda ve çarşılarda gezerek önüne gelen herkese sorular sorarak gerçekten ne yapmayı hedefliyordu? Sokrates'e göre Atina kent devleti, soylu ama iri ve hantal bir ata benzemektedir. Bunun için kentin uyanıp kendine gelmesi için bir at sineğine ihtiyaç duyulmaktadır. Dolayısıyla Sokrates'e göre Tanrı, kendisini peşlerinden koşarak her birini uyandıracak, nasihat edecek ve azarlayacak bir at sineği ola- 
rak kentin başına sarmıştır. (Platon 2019a, s. 49). Biraz daha yakından bakıldığında Sokrates'in kendini bir at sineği olarak addetmesinin temelinde, öğrenim görmemiş olan bir kimsenin kendi benliğine karşı eleştirici bir tavır takınması beklenemeyeceği için, onu sarkıp uyandıracak bir otoriteye gereksinim olduğunu düşünmesinde yatmaktadır. Fakat bu otoriterlik öğesi Sokrates'in öğretisinde fevkalade iyi dengelenmiştir. Çünkü otoriteye bundan öte bir hak tanımamaktadır. Gerçek öğretmen, ancak eğitilmemişin yoksun olduğu benlik-eleştirisine sahip olduğunu ortaya koyarak kendini kanıtlayabilir. Sokrates'in kendi kendine yüklediği, insanları dogmatik uykularından sarsıp uyandırma görevi, böyle temellendirilmiş olabilirdi. Sokrates, yanı sıra bu eğitim görevinin siyasal bir görev olduğuna da inanıyordu. $\mathrm{O}$, şehrin siyasal yaşamını düzeltme yolunun, yurttaşları benlik-eleştirisi yapacak biçimde eğitmek olduğu duygusuna kapılmıştı. Bu anlamdadır ki, insanları gerçek çıkarlarını artıracak yönde etkilemek yerine, halkı pohpohlayanlara karşılık, Sokrates, kendisinin "gününün yegâne siyasetçisi" olduğunu iddia etmişti (Popper 2018, s.143).

Cornford'un (2019, s.32-33) deyimiyle Sokrates; gençlere, bir insanın tam özgürlüğünü kazanmak için, kabul edilmiş tüm davranış ilkelerini sorgulamalarını gerektiğini ve tüm ahlaki soruları kendi kendilerine yargılamayı hedeflemeleri gerektiği üzerinde ısrar ediyordu. Ailelerin ve toplumun çocuklarını titizlikle kuşattığı ahlaki dayanak ve payandayı kesmek bakımından ahlak bozuyordu. Sokrates aslında, insan türünün tarihi boyunca, aileden millete her büyüklükteki insan grupların bir arada tutan ne varsa, yani otoriteye itaat ve geleneğe riayet ahlakını ve sosyal baskının etkilerini zayıflatıyordu. Ya da daha ziyade, bu baskı ve kısıtlama ahlakının çok ötesine geçiyor, Dağ Vaazının Musa Yasası'nın³ ötesine geçmesi gibi başka tür bir ahlak başlatıyordu.

\footnotetext{
3 Musa Yasası; "Yasa terimi Kitab-ı Mukaddes'in Yunanca çevirisi olan Septuaginta'da Nómoৎ (Nómos) kelimesiyle karşılanmaktadır. Yasa, en basit şekilde Yahudiler için yerine getirilecek yükümlülükler ve kaçınılması gereken yasaklar anlamına gelmektedir. Yasa, bu yüzden uyulması istenen ilkeleri ve uygulanması talep edilen ritüeller ile törenleri içermektedir. Inanışa göre, İsrail'in Tanrı'sı ile Yahudiler arasında yapılmış anlaşmanın tezahürü Yasa'da ortaya çıkmaktadır. Bu kapsamdaki inanışa göre, Tanrı tarafından peygamberi Musa'ya Sina Dağı'nda 613 tane Yasa (Nó $\mu \circ$ ) (mitzvot) verilmiştir ve bunlar Yahudiliğin temel köşe taşlarını teşkil etmektedir. Bu Yasa'ların en meşhur olanları diğer dinlerin taraftarları tarafından bile "On Emir" şeklinde bilinmekte ve saygı görmektedir. "On Emir", birçok kimse tarafından Tanrı'nın bütün insanlar için ebedi ve değişmez iradesinin ifadesi olarak değer görmektedir." (Duygu 2018, s. 286).
} 
Yukarıdaki söylemler ışığında o halde Sokrates'in esas itibariyle ortaya attığı, varolan bir yönetimi, toplumu veyahut düzeni eleştiren dini ve politik bir doktrindir. Her zaman için toplumu kınamaya yönelik olağandışı bir tutumdur. Arzu edilen bir topluma ya da yaşam biçimine ilişkin bir görüştür. Mevcut olan bir düzenden istenilen diğer bir düzene geçmenin bir yoludur. Dolayısıyla Sokrates'in yegâne amacı, her zaman siyasal, dini ve toplumsal değişimdir. Bu denli bir değişimin gerçekleşebilmesi için de ne olursa olsun tüm riskleri göz önüne alarak kararlı adımlarla yol almaktır. Bu yolda gerektiğinde canını bile hiç çekinmeden ortaya koymaktan geri durmamaktır.

Bir toplumda siyaset ve din gibi hassas konularda, geçerli olan birtakım teamüller söz konusudur. Eğer bu teamüllerin biraz dışına çıkıldığında toplumun çözülmesi ve tamamen dışına çıkıldığında ise devletin çöküşü kaçınılmaz olmaktadır. Nihayetinde bir toplum, daha önce mevcut kurum ya da kurumların, örf, adet ve geleneklerin ya olduğu gibi ya da bunların düzeltilmesi veyahut oraya uyarlanmasiyla kendini tekrardan var etmektedir. Dolayısıyla eski teamüllerin bir bütün olarak ortadan kalkması söz konusu değildir. Deyim yerindeyse ne hiçbir düzen bir bütün olarak gökten zembille iner, ne de hiçbir düzen tümüyle hemen yerden bitiverir. O halde diğer Yunan kent devletlerinde olduğu gibi Atina kent devleti de aynı şekilde, kısmi olsa da, bazı teamüller üzerine kurulu bir devlet olduğu aşikârdır.

Sokrates de böylelikle yerleşik olan bazı teamüller üzerine kurulu bir kentte, kendine adeta aksaklıkları düzeltme misyonu yükleyerek insanlara hem dini ve hem de siyasi konularda sürekli soru sorması, onları sorgulamaya yönelterek kafaların karışmasına yol açabileceği ve bundan dolayı daha sonra insanların bu teamüllerin dışına çıkacak olasılığını da beraberinde getireceği için gerek yönetimde bulunanlar ve gerek bazı egemen kişiler tarafından endişeye ya da korkuya neden olabildiğini söyleyebiliriz. Bu nedenle hiçbir yönetim ve toplumun çoğunluğu olmak üzere, geçmiş dâhil olmakla beraber özellikle günümüzde bile tamamen geçerli olmak üzere gerek siyasi ve gerek din gibi hassas konularda, mevcut düzenin sorgulanmasina maruz kalarak devletin ya da toplumun çözülme veyahut çöküş riskine göz yummaz. Aksi durumda, bunun için tarih sayfalarına bakmak yeterli olacaktır, çok şiddetli çatışmaların olduğunu ve bu çatışmaların sonucunda neler olduğunu burada söylemeye gerek olmadığını düşünüyoruz.

Kimilerine göre aslında Sokrates'in yaptığı, Atina sokaklarında, pazarlarında ve çarşılarında yurttaşlarla yaptı̆̆ en iyi yaşam tarzına ilişkin fikirleri 
tartışmak olsa da, Atina'nın önde gelen bazı vatandaşları (egemen sınıf), aksine Sokrates'i kendi siyasal yaşamlarının getirdiği konumlarını kaybetmemek için büyük bir tehdit olarak görüyorlardı (Arnhart 2011, s. 27). Böylelikle bu da yeni bir yaşam ilkesi keşfetmek ve korkup taviz vermeden onu duyurmak, kısıtlamaları kaldırılması gereken bir ahlak anlayışına göre yaşayan toplumun kızgınlığını üzerine çekmek demektir. Ayrıca, hâlihazırda bu kısıtlamaların içine sığmayan, yeni ahlaki ilkeyi olumlu sonuçlarıyla birlikte kavrayamayan kimi kişiler tarafından yanlış anlaşılma riskini de beraberinde getirir (Cornford 2019, s. 33). Dolayısıyla tehdit eder bir algı içerisinde olan egemen yurttaşların/sınıfların da kendi egemen konumlarını kaybetmemek adına, bu duruma herhangi bir tepki de bulunmaması pekâlâ düşünülemez. Tıpkı bir zamanlar Atina kentinin ve devletinin Tanrılarına inanmadığı gerekçesiyle Yunan dünyasında ilk olarak dinsizlikle suçlanan ve görüşlerinden ötürü mahkemeye verilen Anaksagoras'ın (Arslan 2010a, s.289) tehdit olarak algilanması gibi.

Yukarıda zikredilen sebeplerden dolayı Atina yasaları ve mevcut yönetimi göz önüne alındığında Sokrates'in adı geçen eylemleri bağlamında, Atina kent devleti tarafından tehdit eder bir kişilik çerçevesi içerisinde ele alınmasında daha doğal ne olabilir? Her ne kadar Sokrates'in eylemlerinin ya da söylemlerinin suç teşkil ettiği yasalarda tam bir karşıllğ̆ olmasa da, yönetim için onun tehdit eder bir kişilik olarak algılanması nedeniyle onun suç işlediği yönünde bir kanaate yol açmıştır. Bu bağlamda değerlendirildiğinde Atina kent devletinin bir yurttaşı olarak yasaları kabul eden ve aynı zamanda bu yasalara saygılı olunmasını söyleyen Sokrates'in sokakta, çarşıda ve pazarda gezerek hem dini hem de siyasi konularda insanların kafalarını karıştırması, yasalara karşı gerek saygisızlık ettiği ve gerek onlara karşı gelerek suç işlediği söylenebilir. Böylelikle Sokrates'in bu bağlamda sergilediği eylemleri ile yasalara karşı bakışında bir tezatlık olduğunu söylemekte herhangi bir beis görünmemektedir. Bunu şöyle ifade etmek gerekirse, yasalara karşı saygılı olunmasını söyleyen Sokrates' in, aynı zamanda aksi yönde davranışlar sergilemesi, onun düşünceleri ve sergilediği eylemleri arasında paralellik olmadığını bize açıkça göstermektedir. 


\section{Sokrates'in Hak Kavramı Bağlamında Düşünceleri ve Yasalar}

Yukarıda birinci soruya açılık getirdikten sonra ikinci soruya yani "herkesin yasalara karşı saygılı olması gerektiği ve kendisinin de saygılı olduğunu söyleyen ama bu yasalar gereği suçlu bulunan Sokrates'in, gerek kendisinin, arkadaşları ve gerek bizler tarafından bu durumun bir haksızlık olarak değerlendirilmesi ne kadar makuldür?"sorusuna geçebiliriz. Öncelikle Sokrates içinde bulunduğu durumla ilgili kendisine haksızlık yapıldığını, eşi ile arasında geçen konuşmada belirtmektedir. Sokrates' in kendisine eşi tarafindan, "haksız yere ölüyorsun" demesi üzerine, "yoksa sen ölümü hak etmiş olmamı mı isterdin?" (Laertios 2019, s.82) diyerek kendisine haksızlık yapıld1ğını gayet açık bir şekilde dile getirmiştir. Sokrates'in eşinin Sokrates ölüme giderken haksızlık yönündeki söylemini, aslında bütün bir hadise ile ilgili düşündüğü şeklinde yorumlamak gerekir. Nitekim mantık çerçevesi içerisinde ele alındığında Sokrates' in eşinin, Sokrates' in yargılanmasını haksızlık olarak nitelendirmeyip sadece Sokrates ölüme giderken durumu haksızlık olarak nitelendirmesi düşünülemez. Dolayısıyla Sokrates'in eşi için, Sokrates'in tutuklanmasından idamına kadar olan sürecin tamamı hakkaniyet ölçütleri içerisinde olmayan bir durum olarak tezahür ettiğini söylemek daha makul bir bakış açısıdır. Bununla birlikte Sokrates' in yakın arkadaşları da durumu haksızlık çerçevesi içerisinde değerlendirmektedir. Arkadaşlarının durumu haksızlık olarak değerlendirilmesini, onu hapishaneden ısrarla kaçırma isteklerinden de rahatlıkla anlayabiliriz.

Yukarıda verilen iki örnekten yola çıkıldığında gerek Sokrates'in ve gerek arkadaşlarının duruma bakış açısının, tamamen haksızlık yapıldığı yönünde olduğu görülmektedir. Bununla birlikte günümüze kadar insanlar da aynı şekilde vuku bulan hadiseye haksızlık olarak bakma eğilimi içerisindeler. Zaten insanların Sokrates'in isminin hafızalardan hiç silinmemesini, haksızlık çerçevesi içerisinde değerlendirdiklerinden kaynaklanmaktadır.

Sokrates'in, ölümünden bir gün önce hem öğrencisi, hem de en yakın arkadaşı olan Kriton tarafından ziyaretine gelinir ve hapishaneden kaçması için kendisine tekrardan kaçması yönünde tekrardan bir teklif daha yapılır; “Ama son bir kez, sevgili Sokrates, dinle beni de yaşamını kurtar. Çünkü ölümün birden fazla felaket getirecek başıma: Hem bir daha eşini bulamayacağım bir dostumu yitireceğim hem de seni beni iyi tanımayan bir sürü insan, "parayı bastırsaydı onu kurtarabilirdi ama umursamadı", diyecek. İnsanın adının, 
"dostlarından çok parasını önemser"e çıkması kadar utanç verici bir şey olabilir mi? Çokları, bizim yalvarıp yakarmamıza karşın senin buradan çıkmak istemediğine inanmayacak." (Platon 2019b, s. 20). Kriton'un yaptığı kaçma yönündeki bu teklifin içeriğine şöyle bir baktığımızda, Sokrates'in belli bir para karşılığında serbest kalabileceği hemen göze çarpmaktadır. Aynı zamanda Sokrates'in sadece para karşılığında değil, sürgüne gönderilmeyi kabul ederek de gerek esaretten ve en önemlisi gerek idamdan kurtulması mümkün olduğu aşağıdaki satırlarda görülecektir.

Yukarıda değinildiği üzere Sokrates, mahkemedeki savunmasında gerek hapis cezası teklif etseydi, belli bir miktar ödeme yapmayı kabul etseydi veya gerek sürgüne gönderilmeyi teklif etseydi idam cezasından kurtulabilmesinin pek olası olduğunu dile getirmiştik. Sokrates' in mahkeme üyelerine yaptığı savunmasında bunları gayet açık bir şekilde ve özellikle kendisinin dile getirmesi bize daha şaşırtıcı gelmektedir; "yoksa bir para miktarı belirleyerek, para cezasını ödeyene kadar zindanda kalmayı mı yeğlemeliyim? Ancak bu, daha önce söylediklerimle aynı şeydir, çünkü cezayı ödeyebilecek param yok. O zaman sürgünü teklif edeyim! Bu cezayı belki kabul edersiniz. Ama bunu teklif etmek için fazlasıyla canıma düşkün ve yurttaşım olan sizlerin felsefi arayışlarımla sözlerime katlanamadığını, rahatsız olup kızdığını ve onlardan kurtulmak istediğini göz ardı edecek kadar düşüncesiz olmam gerekir. Sizler davranışlarıma katlanamadığınıza göre başkaları nasıl katlansın? Aslında tam aksi geçerli Atinalılar! Bu yaşta bir insanın buradan ayrılması, bir kentten diğerine geçerek yaşaması, her yerden kovulması ne kadar hoş olurdu? Nereye gidersem gideyim, gençler burada olduğu gibi etrafıma toplanıp sözlerime değer verirdi. Onları geri çevirsem, büyüklerini beni sürgüne yollamaya ikna ederdi. Geri çevirmediğim takdirde, onlar yüzünden bu kez babalarıyla akrabaları beni kovardı" (Platon 2019a, s.57-58).

Yukarıdaki söylemlerden de anlaşılacağı üzere Sokrates, mahkeme tarafından kendisine verilen gerek hapis cezasına ve gerek daha sonra verilen idam cezasına çok fazla direnmeden adeta kaderine razıymış gibi görünmektedir. Bunun diğer bir ifadesi de acaba, Sokrates' in kendisinin içine düştüğü bu durum ile ilgili haksız olduğunun bilincinde olduğu ya da bilincine vardığ 1 için çok da tepki vermediği şeklinde yorumlanamaz mı? Çünkü Sokrates idam edilmeden bir gün önce, kendisine arkadaşları tarafından yapılan kaçma teklifini de daha önce de belirtilen gerekçeleri öne sürerek aynı şekilde ret etmesi de bunun en açık göstergesi olduğu söylenebilir. 
Sokrates kendini savunması sırasında, "şimdi düşündüğüm gibi ve anladığım kadarıyla tanrı beni felsefe yapmak, diğer insanları ve kendimi incelemek üzere görevlendirmişken, ölümden ya da başka bir tehditten çekinerek firar etsem büyük bir suç işlemiş olurdum". (Platon 2019a, s. 47) diyerek firar etmeyeceğinin önceden altını çizmektedir. Bundan dolayı Sokrates, arkadaşı olan Kriton tarafından kendisine yapılan kaçma teklifine de yasaları gerekçe göstererek şöyle yanıt vermektedir; "Diyelim ki, tam buradan kaçacağımız sırada; Yasalar ve Devlet karşımıza dikilseler ve dile gelip bize şunları sorsalar: Söyle bize Sokrates, nedir bu yaptığın? Bu işte amacın, bizi-hem Yasaları hem de tüm devlet'i-elinden geldiği kadarıla yıkmak değil de nedir? Hangi devlet ayakta kalabilir, orada yargı kararlarının hiçbir gücü kalmaz ve kişiler onları ayaklar altına alabilirse?" Ne yanıt veririz. Kriton, bu soruya ve benzerlerine? İnsan -hele iyi bir konuşmacıysa- yargı kararlarının uygulanmasını gerektiren ve bizim çiğnediğimiz bu yasayı savunmak için neler söylemez? Biz buna karşılık, "Devlet bize haksızlık yaptı; davamızda yanlış karar verdi," yanıtını mı veririz? Böyle mi yanıt vermeliyiz yoksa başka bir şey mi söylemeliyiz?" (Platon 2019a, s.32)

Sokrates, arkadaşı Kriton ile karşılıklı yaptığı konuşmasına şöyle devam etmektedir; "Haydi Sokrates, biz ki seni yetiştirdik, gel dinle bizi: Ne çocuklarını, ne yaşamını ne de başka bir şeyi adaletin üstüne koyma ki, Hades ${ }^{4^{\prime}} \mathrm{e}$ indiğinde bunları söyleyip oranın yargıçları önünde kendini savunabilesin... Eğer bugün öteki dünyaya gidersen, biz yasaların değil, insanların haksızlığının kurbanı olmuş biri gibi gideceksin. Tersine kaçarsan, onursuz bir biçimde eğriliğe eğrilikle, kötülüğe kötülükle yanıt verip seni bize bağlayan anlaşma ve sözleşmeleri çiğnersen, korumak zorunda olduğun kişiler, kendine, dostlarına, yurduna ve bizlere kötülük etmiş olursun" (Platon 2019a, s.38-39). Bu söylemlerden yola çıkıldığında Sokrates için, özellikle gerek devletin ve gerek bu devletin yasalarının ne kadar önemli olduğunu rahatlıkla görebilmekteyiz. Bunun içindir ki, şeriatın kestiği parmak acımaz misali, Sokrates de kendisi hakkında verilen hapis cezasına ve ardından gelen idam kararına çok tepki vermeyerek kaçmayı aklından geçirmediğini söylemek için herhangi bir sebep bulunmamaktadır.

\footnotetext{
${ }^{4}$ Hades; Yunan mitolojine göre tanrı Zeus'un erkek kardeşi olup, kendisi de bir tanrıdır. Hades, yeraltı dünyasının hükümdarı ve ölülerin efendisidir (Rosenberg 2000, s.33).
} 
Sokrates arkadaşı olan Kriton'a her ne kadar söylemlerinin başka bazı yerlerinde kaçmaya teşebbüs ettiği sıralarda kendisine yardımcı olacak herhangi kimseyi riske edemeyeceğinin ve Atina halkının firar olayında kendisini haksız görüp buna rıza göstermeyeceğinin (Platon 2019a, s.21) altını çizse de, Sokrates'in kaçmayı ret etmesinde öne sürdüğü gerekçelerde, ön plana çıkan daha çok kentin yasaları olduğu açıkça görülmektedir. Sokrates'in hapishaneden ya da idamdan kurtulmasında daha çok engel olan ya da engel olarak gören bizzat kentin yasaları olduğuna göre, bu durumda Sokrates için yasaların büyük bir bağlayıcılığı söz konusudur. Öyleyse Sokrates için yasaların bağlayıcılığının olmasının sebebi, onların doğru yasalar olması olarak yorumlanabilir. Aksi takdirde böylesine hayati öneme sahip bir hadisede, Sokrates gibi biri için yasaların bağlayıcılığı neden bu kadar önemli olsun ki? O halde Sokrates'e yasalarca verilen mahkûmiyet kararı, son derece doğru ve yerinde bir karar olarak telakki edilmelidir. Bu veriler ışığında yola çıkıldığında, Sokrates'in mahkûmiyet kararında herhangi bir haksızlık durumu ortaya çıkmamış olmaktadır. Böylelikle vuku bulan mahkûmiyet kararı gerek Sokrates için, arkadaşları için ve gerek bizler için makul bir olay olarak karşımıza çıkmak durumundadır.

\section{Tartışma ve Sonuç}

Tarihte benzerine çok az rastlanılan ve günümüze kadar bir şekilde hiç unutulmayan mahkûm edilme hadisesini, Sokrates'in kendi düşünce ve eylemleri nedeniyle bir nevi haksız olduğu ya da o günün yasaları karşısında suç işlediği şeklinde okumak gerekir. Ama düşünce ve eylemlerinin haksızlık çerçevesi içerisinde değerlendirmesini daha çok zamanın ve mekânın koşullarına sıkı sıkıya bağlı olduğunu da göz ardı etmemek gerekir. Nihayetinde zamanın, milattan önceki bir tarih kesitini ve mekân olarak da Yunan dünyasının hâkim olduğu bir coğrafyayı kapsadığını göz önünde bulundurmak zorunluluğu vardır. Çünkü milattan önceki bir zaman kesiti ve Yunan dünyasının gerek siyasi ve gerek dini koşulları, Sokrates gibi geniş bir perspektife sahip düşünürün yaşam biçimine pek de uymadığını söyleyebiliriz. Hatta tamamen birbirine zit olduğunu söylemek daha doğru bir ifade olur. Tersinden söylenildiğinde, Sokrates'in kendi düşünceleri itibarıyla, her ne kadar başka yerlere nazaran demokratik olduğu hatta doğrudan demokrasinin ilk örneğinin yaşandığı söylenilen bir mekânda (Atina kent devleti) ve zamanda 
(M.Ö. 470-399) yaşasa da, buna rağmen kendi zamanın çok ötesinde bir düşünür olduğunu söylersek hiç de yanlış olmayacaktır. Hadise bu minvalde değerlendirildiğinde konunun daha iyi anlaşılacağını umuyoruz.

Sokrates'in yaşadığı milattan önceki dünya konjonktüründe genel itibariyle, çok tanrılı bir inanç anlayışının hâkim olduğu pekâlâ bilinmektedir. Her devletin kendine özgü bir tanrısı olduğu gibi, bazen devletlerin birçok tanrıya da sahip olduğu görülebilmektedir. Aynı şekilde Yunan coğrafyasında mevcut olan kent devletlerinde de çok tanrılı (Zeus, Poseidon, Hades, Hera ve Demeter gibi tanrılar) bir inanç anlayışı mevcuttur. Bu tanrılar devlet ve toplum için dokunulmazlık babında bir tür hüviyete sahiptirler. Bu nedenle devletin tanrısına ya da tanrılarına olmazsa olmaz şeklinde bir inanma zorunluluğu her ne kadar söz konusu olmasa da, onları kaldırıp yerine başkalarını ikame etmeye çalışmak ya da etrafta onlar hakkında olumsuz bir şekilde söylemlerde bulunmak pek de mümkün gözükmemektedir. Aksi takdirde ölüm cezasına çarpıtılabilir, en iyi ihtimalle sürgüne gönderilebilirsiniz. Eğer bu iki ceza şekline maruz kalınmazsa bile toplumsal baskılar nedeniyle, kentte yaşama olasılığ 1 çok düşük hale gelmektedir.

Milattan önce Yunan toplumuna özgü şehir devletleri şeklinde oluşmuş bir siyasal örgütlenme söz konusudur. Siyasal ve sosyal alanda örgütlenmiş bu şehir devleti veya devletlerin en büyük özellikleri; dışa karşı tamamen bağımsız olabilmek, kendi yasalarını yapabilmek, uygulayabilmek ve mümkün mertebe ekonomik olarak kendi kendine yeterli olabilmektir (Arslan 2010a, s. 54). Bilindiği üzere Atina da bir kent devletidir ve Atina kent devletinin de kendine özgü siyasal bir yapısı vardır. Bu siyasal yapının en belirgin özelliğinden biri, onun başka yerlere benzemeyen kendi iç dinamiklerine sahip olmasıdır. Özellikle demokrasinin ilk olarak burada filizlenip serpildiği bir yer ve ayn zamanda yönetim biçimi değişikliği bağlamında iç çatışmaların yoğunlukla yaşanması bunu ispatlamaktadır. Atina kent devletinin siyasal tarihine bakıldığında yönetimde kimlerin başa geçeceği konusunda iç çatışmaların sıklıkla yaşandığı daha net anlaşılacaktır. İktidara hangi yönetim biçimi gelirse gelsin, nihayetinde karşıtların ya bunu sineye çekerek kabul etmesi, kabul etmeyerek de ya ölmesi ya da kenti terk etmesi gerekmektedir.

Sokrates, Yunan dünyasının çok tanrılı bir inanç anlayışının hâkim olduğu ve aynı şekilde siyasal erkin çoğu zaman el değiştirdiği ama siyasal yapının daha çok demokrasi taraftarlarının elinde olduğu bir mekânda ve zaman diliminde yaşamıştır. Ancak inanç anlayışının ne olduğu ve siyasal erkin 
kim ya da kimler tarafından oluştuğunun pek de bir önemi yoktur. Mevcut hâkim siyasal yapı ve inanç ne olursa olsun, onun dışına çıkılması ancak köklü bir değişimin yaşanmasıyla mümkün olabilmektedir. Bu değişimin olabilmesi de birçok çatışmaların yaşanmasını gerektirmektedir. Bunun d1şında kişi, kişilerin ya da toplumun yapabileceği pek bir şey olduğu söylenemez. Aksi durumda bunun olumsuz sonuçlarına katlanılması gerekir. Mevcut hâkim siyasal yapı fark etmeksizin, Sokrates'in de böyle hâkim bir yapı içerisinde yaptıkları ya da yapmak istedikleri, mevcut düzenin değiştirilmesine yönelik egemenler tarafından bir tehdit çerçevesi içerisinde algılanmıştır. $\mathrm{Bu}$ algı içerisinde değerlendirilen düşünce ile eylemlerin, mekânın ve zamanın şartları da göz önüne alındığında suç olarak değerlendirilmesi kadar doğal bir şey olmadığını söylemek gerek.

Sokrates'in içinde bulunduğu zamanın ve mekânın genel şartları göz önüne alındığında eylemlerin suç teşkil ettiğini ve bu nedenle cezaya maruz kalmasının gayet yerinde olduğunu belirttik. Böylelikle Sokrates'in sergilediği eylemleri ile yasalara karşı bakışı arasında bir tezatlık olduğu ve aynı şekilde cezaya maruz kaldığında herhangi bir haksızlık durumunun olmadığı ortaya çıkmış oldu. Ancak tüm bunların yanında genel olarak düşünüldüğünde Sokrates' in eylemlerinin, temel insan hakları ya da ifade özgürlüğü çerçevesi içerisinde değerlendirildiğinde, kendisine büyük bir haksızlık yapıldığının altını çizmek gerekir. Ama daha önce de söylenildiği üzere Sokrates gibi bir düşünürün belki de en büyük talihsizliği, böyle bir zaman ve mekânda yaşamış olmasıdır. Çünkü hukuk devleti, düşünce ve ifade özgürlüğü, erkler ayrılığı, özgür seçimler, sivil toplum katılımı vs. gibi kavramlar günümüz dünyasında mevcut olan demokrasilerinde bile halen üzerinde tam bir konsensüs sağlanamamışken, o günün Atina demokrasisinde bu kavramlar üzerinde bir konsensüs sağlanmış olması düşünülemez. Sonuç olarak insanın kendi düşünce ve ifadelerinde özgür olmadığı bir mekân ile zaman dilimi (belki de böyle bir zaman dilimi Sokrates gibiler için hiç olmayacak), Sokrates gibi zamanın çok ötesinde olan bir düşünürün hayatına mal olmuştur. 


\title{
EXTENDED ABSTRACT
}

\section{Socrates: Inconsistency of His Thought and Actions}

\author{
Ferhat Kutluay \\ Siirt University
}

There are many important names in the history of thought, which are frequently mentioned. It is immediately apparent that the Greek philosopher Socrates, who lived in a very distant past, undoubtedly with his thoughts and actions he demonstrated, is at the top of these names. One of the main reasons for this is that the people who came across barefoot in the streets, bazaars and markets of Athens, but mostly young people, confused with the confusion of the city of Athens where they lived, and even they were executed with the claim that they invented other gods instead. Because in a city based on some established settlements, Socrates, by putting himself a mission to correct the hitches, constantly asking people about both religious and political issues, it may lead to confusion by asking them to question, and therefore it will bring the possibility that people will come out of these practices. has been seen as a cause for anxiety or fear by both the rulers and some sovereign people. Therefore, Socrates was convicted by the supporters of democracy under the rule of the city of Athens and as a result BC. In 399, he was convinced that the Athens city court was guilty of five hundred people by two hundred and eighty votes against two hundred and twenty, and was later executed by making him poisoned. Another reason why he is important is that Socrates was recorded in the history of thought as the first philosopher who died / died by being sentenced to death among philosophers in the history of thought. The fact that Socrates was convicted and later executed for the charges against him constituted the conviction that he has died dramatically and at the same time unfairly, or more accurately, by virtually everyone.

In his defense at the court, Socrates described the accusations against him that he did not believe in the gods of the city and that he took the youth out of the way as injustice. Because Socrates has expressed many times that he believes in God and is respectful to the law. However, he could not escape being thrown in jail. While Socrates was in prison, he was offered to escape with his close friend Kriton, along with his other friends, but Socrates did not accept this offer by citing the laws of Athens, the city or state in which he 
lived. In other words, Socrates firmly rejected the idea of escaping in the context of how he respects the laws of the city in which he lives, and in the same way that everyone should respect the law. At the same time, Socrates, who regarded himself as a citizen of the city of Athens or as a citizen of the city of Athens, insisted that he would give up his thoughts against religion / political accusations against him and, if acquitted, he would again put his thoughts into action. His attitude emerges as a reflection of how determined and equally consistent in his thoughts and actions.

A closer look at the relationship between Socrates' thoughts and actions reveals that he is not in consistency. In this context, two basic questions arise that should be asked. The first question to be asked is; If Socrates does not escape from the prison by signing respect for the law, does he not show that he is aware that Socrates' initial actions constitute a crime or at least will constitute a crime? In other words, can it not be said that Socrates does not escape by suggesting the laws of the city he lives in, despite the fact that he has the opportunity in the prison with his actions on the road from the streets to the prison, and there is a contradiction in the point of view of the laws with his actions. Finally, if it is desired to respect the law, it is necessary to avoid such actions as much as possible. No, if such actions are still ongoing, it is a kind of paradox to demand respect for the law and respect for others. Second question; How right would it be to be described as an injustice for both himself, his wife, friends, and us, both of us who want everyone to be respectful of the law and that he is also respectful of the law but is guilty of these laws?

The above questions question the goals of Socrates in his actions on the streets. To underline here is to analyze whether there is consistency between Plato's and some other thinkers 'Socrates' own life, thoughts and actions. Based on this, this study; It is not to find out what faith or ideology Socrates has, or whether his belief and ideology fits the city he lives in, but on the contrary, he is asked to ask people by visiting the streets, markets and bazaars of the city of Athens, which is known as a citizen of the city of Athens. It tries to find out whether it confuses as it allegedly matters on political and religious matters, which are always sensitive to society and government, and if it is confused, it is against the law.As a result, in this study; Noting that it is necessary to respect the law and trying to show that it acts in this direction, Socrates turned out to be against the law, and it was understood that he was convicted 
by being found guilty as well as a contrast between his own actions and thoughts.

\section{Kaynakça / References}

Aristoteles. (2017). Atinalıların devleti. (çev. G. Birol), Eskişehir: Dorlion Yayınları. Aristoteles. (2018). Politika. (çev. F. Akderin), İstanbul: Say Yayınları.

Arnhart, L. (2011). Siyasi düşünce tarihi:Platon'dan Rawls'a. (çev. A. Kemal Bayram), Ankara: Adres Yayınları.

Arslan, A. (2010). İlkçă̆ felsefe tarihi-Sofistlerden Platon'a, (1. Cilt). İstanbul: İstanbul Bilgi Üniversitesi Yayınları.

Arslan, A. (2010). Ilkçă̆ felsefe tarihi-Sofistlerden Platon'a. (2. Cilt). İstanbul: İstanbul Bilgi Üniversitesi Yayınları.

Cevizci, A. (2010). Felsefe tarihi-Thales'ten Baudrillard'a. İstanbul: Say Yayınları.

Cevizci, A. (2013). Paradigma felsefe sözlü̈̆̈̈. İstanbul: Paradigma Yayınları.

Conford, F. M. (2019). Sokrates Öncesi ve Sonrası, (çev. C. Şengör ve S. Onan), İstanbul: İş Bankası Kültür Yayınları.

Direk, Z. (2014).Derrida ve laiklik. Temaşa Erciyes Üniversitesi Felsefe Bölümü̈ Dergisi,1, 54.

Duygu, Z. (2018). İsa ve Musa yasası meselesi. Bilimname Dergisi, 1(35), 286.

Güvenç, B. (1995). Kültür ve demokrasi. İstanbul: Gündoğan Yayınları.

Laertios, D. (2019). Ünlü filozoflarm yaşamları ve öğretileri. (çev. C. Şentuna), İstanbul: Yapı Kredi Yayınları.

Magee, B. (2001). Büyük filozoflar-Platon'dan Wittgenstein'a Batı felsefesi. (çev. A. Cevizci), İstanbul: Paradigma Yayınları.

Montesquieu. (2016). Kanunların ruhu üzerine. (çev. Doruk Can Koçak), İstanbul: Doruk Yayınları.

Platon. (2019). Sokrates'in savunmast:Euthyphron, Apologia, Kriton, Phadion. (çev. A. Çokona), İstanbul: İş Bankası Yayınları.

Platon. (2019). Kriton ya da görev üstüne. (çev. S. Rifat), İstanbul: Can Yayınları.

Popper, K. R. (2018).Açk toplum ve düşmanları. (çev. M.Tunçay),Ankara: Liberte Yayınları.

Rosenborg, D. (2000). Dünya Mitolojisi, (çev. K. Aktan), Ankara: İmge Kitabevi.

Tekin, O. (1998). Eski Yunan tarihi. İstanbul: İletişim Yayınları.

Whitehead, A. N. (1979). Proces and realty: An essay in cosmology. New York: Free Press. 


\section{Kaynakça Bilgisi / Citation Information}

Kutluay, F. (2020). Sokrates: Düşünce ile eylemlerinin tutarsızlığı. OPUSUluslararası Toplum Araştırmaları Dergisi, 15(26), 4644-4664. DOI: 10.26466/opus.672459 